\title{
Correction to: Prophylactic Intraperitoneal Onlay Mesh Following Midline Laparotomy_Long-Term Results of a Randomized Controlled Trial
}

\author{
Philippe M. Glauser ${ }^{1,2} \cdot$ Philippe Brosi $^{1,3} \cdot$ Benjamin Speich $^{1,4} \cdot$ Samuel A. Käser ${ }^{1,3}$ • \\ Andres Heigl $^{1}$ - Robert Rosenberg ${ }^{1}$ - Christoph A. Maurer ${ }^{1,5}$
}

Published online: 29 March 2019

(C) Société Internationale de Chirurgie 2019

\section{Correction to: World J Surg}

$$
\text { https://doi.org/10.1007/s00268-019-04964-6 }
$$

In the original version of the article, Philippe $M$. Glauser's, Philippe Brosi's, Benjamin Speich's, Samuel A. Käser's, Andres Heigl's, and Christoph A. Maurer's first and last names were interchanged. The names are correct as reflected here. The original article has been corrected.

Publisher's Note Springer Nature remains neutral with regard to jurisdictional claims in published maps and institutional affiliations.

The original article can be found online at https://doi.org/10.1007/ s00268-019-04964-6.

\section{Christoph A. Maurer}

christoph.maurer@hin.ch

1 Department of Surgery, Hospital of Baselland, University of Basel, Liestal, Switzerland

2 Department of General Surgery, University Hospital Basel, Basel, Switzerland

3 Department of Visceral and Transplant Surgery, University Hospital Zürich, Zurich, Switzerland

4 University of Basel and University Hospital Basel, Basel Institute for Clinical Epidemiology and Biostatistics, Department of Clinical Research, Basel, Switzerland

5 Professor of Surgery, Former Chairman of Surgical Department of Liestal, Hirslanden Private Clinic Group, Hirslanden Clinic Beau-Site, Schänzlistrasse 1, 3000 Bern, Switzerland 